\title{
19. A LOWER EOCENE SHELL BED AND SOME QUATERNARY MOLLUSKS FROM ODP LEG 112 OFF PERU1
}

\author{
Herbert $\mathrm{Hagn}^{2}$ and Erlend Martini ${ }^{3}$
}

\begin{abstract}
Mollusks are reported from the Pleistocene at Sites 680,684 , and 688 off Peru. They include representatives of the genera Calyptraea, Chlamys, Nuculana, Odostomia, as well as the families Buccinidae and Veneridae. In the lower Eocene at Site 688, a silty limestone containing common Limidae is described and its microfacies discussed.
\end{abstract}

\section{INTRODUCTION}

During Leg 112, mollusks were found in the Quaternary of Sites 680, 684, and 686, as well as in the lower Eocene at Site 688 off Peru (Fig. 1). Of special interest is the last occurrence, because representatives of the genus Pseudolimea may occur frequently in the early Eocene Turritella Series of the Negritos Formation in northwest Peru, although these representatives probably were discussed and described as Cardium sp. in Wood et al. (1922). In most cases, mollusks were concentrated in prominent shell layers and may add some paleoenvironmental data to those based on microfossil groups, especially benthic foraminifers. For details of the systematic status of the genera found, see Moore and Teichert (1969).

\section{SITE 680}

At Site $680\left(11^{\circ} 03.90^{\prime} \mathrm{S}, 78^{\circ} 04.67^{\prime} \mathrm{W}\right.$, water depth $\left.252.5 \mathrm{~m}\right)$, a conspicuous occurrence of mollusks was found in the lower part of Cores 112-680A-3H, 112-680B-3H, and Sample 112$680 \mathrm{~B}-4 \mathrm{H}, \mathrm{CC}$. These mollusks were embedded in a diatomand foraminifer-bearing olive gray mud and have been placed in lithologic Unit I, with a minor content of calcareous nannoplankton. According to the calcareous nannoplankton biomarkers, the interval containing the shells is of late Pleistocene age and belongs to nannoplankton Zone NN20 (Gephyrocapsa oceanica Zone). This mollusk assemblage clearly is dominated by a Nuculana species (PI. 1, Figs. 1 and 2) and also contains juvenile specimens of Chlamys sp. (Pl. 1, Figs. 7 and 8 ). Specimens are well preserved and do not indicate transport over larger distances.

\section{SITE 684}

At Site $684\left(8^{\circ} 59.59^{\prime} \mathrm{S}, 79^{\circ} 54.35^{\prime} \mathrm{W}\right.$, water depth $\left.426 \mathrm{~m}\right)$, mollusks were observed at several levels in Core $112-684 \mathrm{~A}$ $2 \mathrm{H}$. The assemblage found in Sample 112-684A-2H-5, 128$132 \mathrm{~cm}$, is similar to that of Site 680 , and includes common Nuculana sp. (Pl. 1, Figs. 1 and 2), few Chlamys sp. (Pl. 1, Figs. 7 and 8), and rare gastropods of the family Buccinidae (Pl. 1, Figs. 5 and 6). These were observed in lithologic Unit IB, which consists of olive gray graded beds of bioturbated fine sand having clay beds containing foraminifers, phosphorite, and few bone fragments. According to the calcareous

\footnotetext{
${ }^{1}$ Suess, E., von Huene, R., et al., 1990. Proc. ODP, Sci. Results, 112: College Station, TX (Ocean Drilling Program).

2 Institut für Paläontologie und historische Geologie der Universität, Richard-Wagner-Str. 10, D-8000 München, Federal Republic of Germany.

${ }^{3}$ Geologisch-Paläontologisches Institut der Universität, Senckenberganlage 32-34, D-6000 Frankfurt am Main, Federal Republic of Germany.
}

nannoplankton, these occurrences belong to nannoplankton Zone NN20 (Gephyrocapsa oceanica Zone) and are of late Pleistocene age (Martini, this volume).

\section{SITE 686}

At Site $686\left(13^{\circ} 28.81^{\prime} \mathrm{S}, 76^{\circ} 53.49^{\prime} \mathrm{W}\right.$, water depth $\left.446.8 \mathrm{~m}\right)$, mollusks were encountered at several levels. Fragments of unidentifiable Veneridae were found in Sample 112-686A21X, CC. A better-preserved assemblage with shells of a common Calyptraea species (Pl. 1, Figs. 3 and 4), Odostomia sp. (Pl. 1, Figs. 9 and 10), and undifferentiated Buccinidae (Pl. 1, Figs. 5 and 6), was observed together with rare crustacean fragments in Sample 112-686A-22X, CC. Both samples have been placed in lithologic Unit IV. Adult specimens of Calyptraea $\mathrm{sp}$. were badly fractured and in a poor state of preservation. Fair numbers of similar fragmented Calyptraea sp. were found in Sample 112-686B-30X, CC, as well as in olive gray diatomaceous mud that was placed in lithologic Unit VI. Poorly preserved calcareous nannoplankton, as well as silicoflagellates, indicate an early Pleistocene age for these occurrences (Martini, this volume). As Calyptraea species normally lived in shallow waters, these may represent displaced assemblages.

\section{SITE 688}

At Site $688\left(11^{\circ} 32.26^{\prime} \mathrm{S}, 78^{\circ} 56.57^{\prime} \mathrm{W}\right.$, water depth 3819.8 $\mathrm{m})$, a silty foraminifer-rich bioclastic limestone was recovered in Core 112-688E-40R; it contained concentrated mollusk shells. Cores from above and below can be placed in the early Eocene calcareous nannoplankton Zone NP13 (Discoaster lodoensis Zone) with the index fossils of this zone present (Martini, this volume). Calcareous nannoplankton assemblages also contain a number of Discolithina and Transversopontis species, which occur commonly in "shallow water" deposits. Benthic foraminifers recovered from Cores 112$688 \mathrm{E}-36 \mathrm{R}$ to $-42 \mathrm{R}$ contain rare shelf-dwelling species in most samples. However, in Sample 112-688E-43R, CC, a middle bathyal and in Sample 112-688E-44R, CC, an upper bathyal benthic assemblage $(150-500 \mathrm{~m})$ of early Eocene age were noted (Resig, this volume).

Several pieces from core-catcher Sample 112-688E-40R, CC (726 m sub-bottom) were studied in thin sections. Sample $112-688 \mathrm{E}-40 \mathrm{R}, \mathrm{CC}$, is a silty to sandy mudstone (PI. 2, Fig. 2). The pelitic and somewhat bituminous matrix contains numerous angular quartz grains, as well as edged, sometimes stemlike, plagioclases. These grains are up to $0.25 \mathrm{~mm}$ in size, have a clear appearance, and are not altered, indicating volcanic activity in the region in early Eocene time. A pyritic impregnation of the matrix is present; glauconite grains are rare; the 


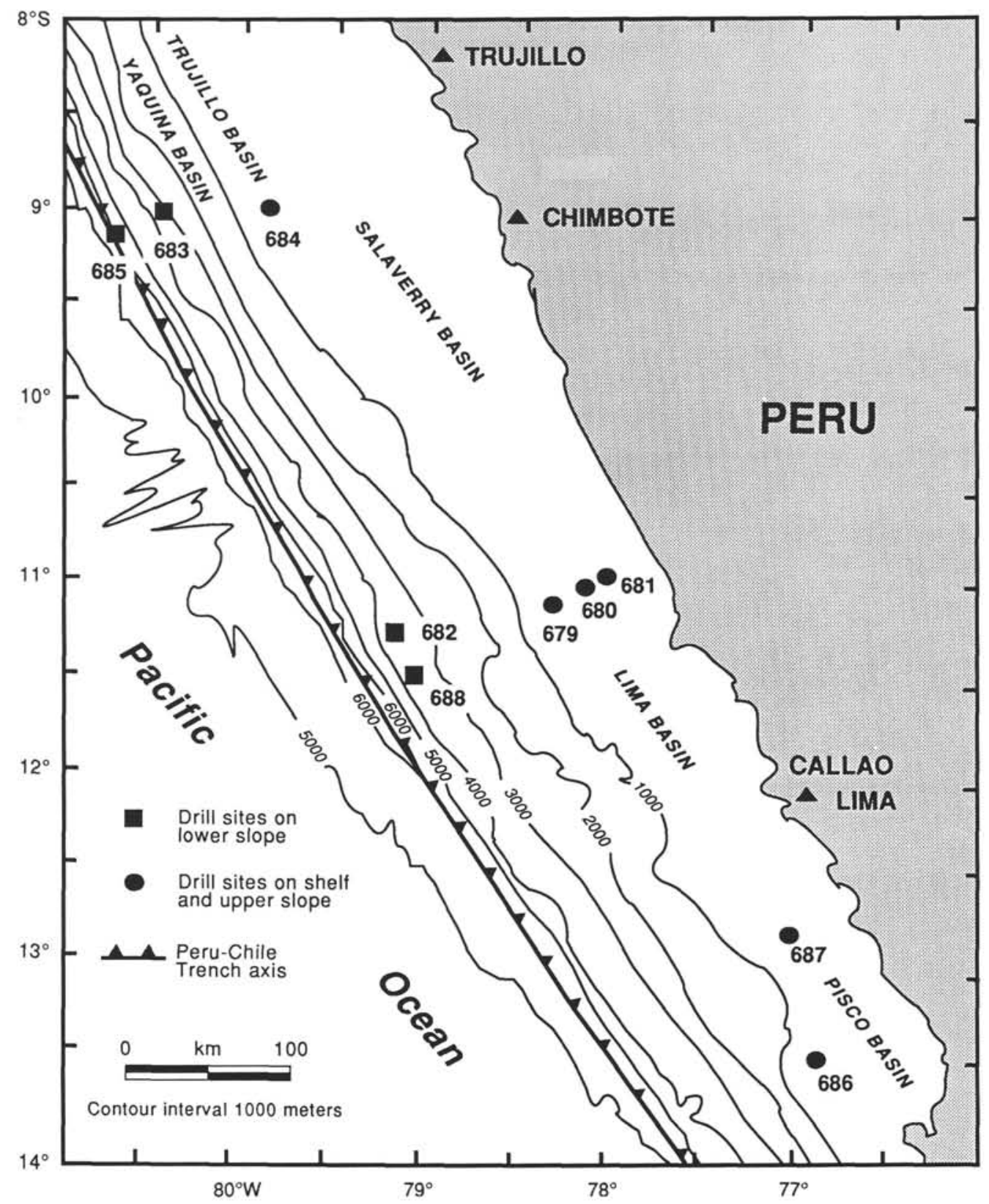

Figure 1. Location of sites drilled during Leg 112 off Peru.

mudstone is bioturbated. Small foraminifers are not common, those present belong to the superfamily Nodosariacea (Lenticulina sp.) as well as to the Buliminacea (Siphogenerina sp.). Planktonic foraminifers were not observed. Metazoans are represented by small, rare sponge spicules; rare ostracods and some debris of echinoderms also were found. Shells of pelecypods are common and have a well-preserved calcite shell structure. Fish scales also are common.

Both Samples 112-688E-40R, CC $(0-4 \mathrm{~cm})$ and $-40 \mathrm{R}, \mathrm{CC}$ $(3-5 \mathrm{~cm})$ are silty mudstones. The siliciclastic components in these samples are smaller in size than in the previous sample, and plagioclases are rare. Smaller foraminifers are common. In addition to Lenticulina $\mathrm{sp}$. and Siphogenerina sp., genera of the Rotaliacea (e.g., Gavelinella sp.) were found. The shells of the pelecypods are partly preserved in their original material (Pl. 1, Figs. 3 and 4) and represent the anisomyarians, which include the Limidae. Other parts of the shells, which were formerly aragonitic, are coarsely recrystallized. Echin- oderm debris is rare, but fish scales are common. Wellpreserved Limidae were found in these samples (Pl. 1, Fig. 1). These forms most probably belong to the genus Pseudolimea Arkell in Douglas and Arkell, 1932 (det. Schairer, München). The shells are ornamented by about 30 radial ribs, between which weaker ribs are intercalated. A Nodosariacea assemblage having numerous specimens of Buliminacea indicates an environment that is not too shallow. Because no planktonic species could be observed, this shell bed probably was deposited on the outer shelf.

\section{DISCUSSION}

The late Pleistocene Nuculana assemblages encountered at Sites 680 and 684 (water depths of 252.5 and $426 \mathrm{~m}$, respectively) are associated with a Bolivina seminuda humilis Assemblage (Resig, this volume). These benthic foraminifers indicate an outer shelf-upper bathyal environment. Modern Nuculana species predominantly live in an outer shelf envi- 
ronment, although some have been seen in intertidal areas, which is in accordance with data provided by benthic foraminifers. Some of these Nuculana occurrences at Site 684 were observed in graded beds, indicating current deposition. However, the shells are well preserved and probably were not transported over larger distances.

The early Pleistocene Calyptraea assemblages at Site 686 were found together with a benthic foraminiferal assemblage, indicating an outer shelf or slightly shallower environment (Resig, this volume). Modern Calyptraea species are found in shallow water and also attached to other mollusks or solid grounds. The concentration of Calyptraea shells in diatomaceous muds, the poor preservation of nearly all adult specimens, and the displaced nannoplankton, diatoms, and silicoflagellates from the lower Miocene and middle to upper Eocene suggest that the Calyptraea assemblages have been transported from shallower waters.

The early Eocene Pseudolimea Assemblage at Site 688 (water depth of $3819.8 \mathrm{~m}$ ) is associated with benthic foraminifers, which indicate a deposition on the outer shelf (see above, and Resig, this volume). Most modern Limidae are distributed throughout the inner shelf. Calcareous nannoplankton found above and below the shell bed also indicate "shallow water," and the shell bed with common Pseudolimea seems to be in situ. The presence of these shallow-water taxa regionally in Core $112-688 \mathrm{E}$ $40 \mathrm{R}$ indicates that a subsidence of approximately $4000 \mathrm{~m}$ can be postulated for these early Eocene beds.

\section{ACKNOWLEDGMENTS}

We thank the Deutsche Forschungsgemeinschaft (Bonn-Bad Godesberg) for supporting this study. Photographs were made by B. Kahl, and the excellent preparation of the Pseudolimea species was done by B. Leipner (both at the Geologisch-Paläontologisches Institut der Universität, Frankfurt am Main). We also thank R. Janssen (Forschungsinstitut und Naturmuseum Senckenberg, Frankfurt am Main) and G. Schairer (Bayerische Staatssammlung für Paläontologie und historische Geologie, München) for their remarks and discussion about the shell assemblages and L. W. Ward and D. J. Dockery III for reviewing this paper.

\section{REFERENCES}

Douglas, J. A., and Arkell, W. J., 1932. Stratigraphical distribution of the Cornbrash. II: The northeastern area. Quat. J. Geol. Soc. (London), 88:112-170.

Moore, R., and Teichert, C. (Eds.), 1969. Treatise on Invertebrate Paleontology, Part N, Vols. 1 and 2, Mollusca 6: Boulder, CO (Geol. Soc. Am.).

Wood, H., Vaughan, T. W., Cushman, J. A., and Hawkins, H. L., 1922. Palaeontology of the Tertiary deposits. In Bosworth, T. O. (Ed.), Geology of the Tertiary and Quaternary periods in the Northwest part of Peru: London (Macmillan), 49-139.

Date of initial receipt: 12 February 1988

Date of acceptance: 12 April 1989

Ms 112B-178 


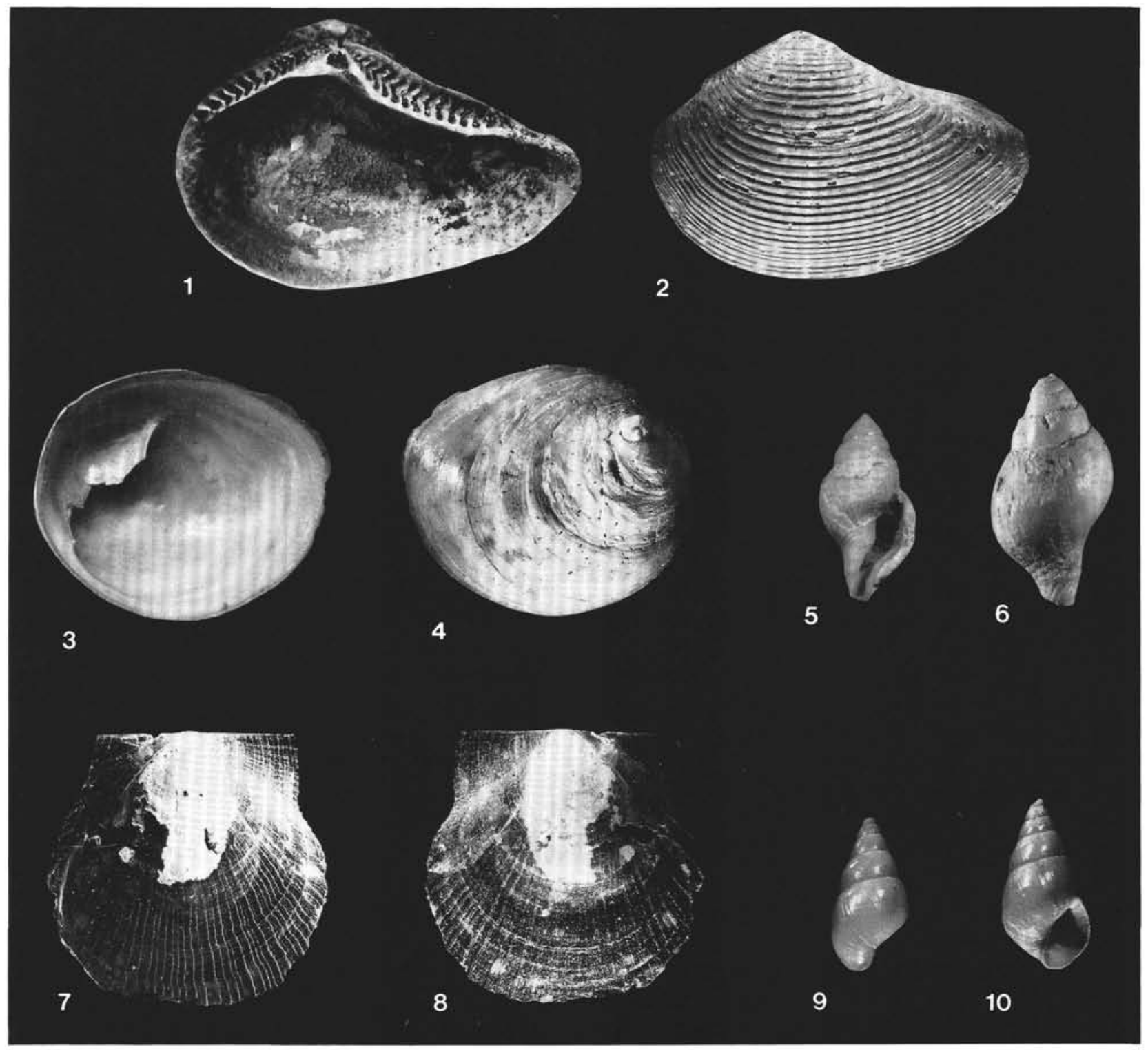

Plate 1. (All specimens approximately 5.5X.) 1, 2. Nuculana sp., Sample 112-680B-3H, CC, late Pleistocene, two different specimens, (1) inner face; (2) outer face. 3, 4. Calyptraea sp., Sample 112-686A-22X, CC, early Pleistocene, (3) inner face; (4) outer face. 5, 6. Buccinidae indet., Sample 112-686A-22X, CC, early Pleistocene, two different specimens. 7, 8. Chlamys sp., Sample 112-680B-3H, CC, late Pleistocene, (7) inner face; (8) outer face. 9, 10. Odostomia sp., Sample 112-686A-22X, CC, early Pleistocene, two different specimens. 


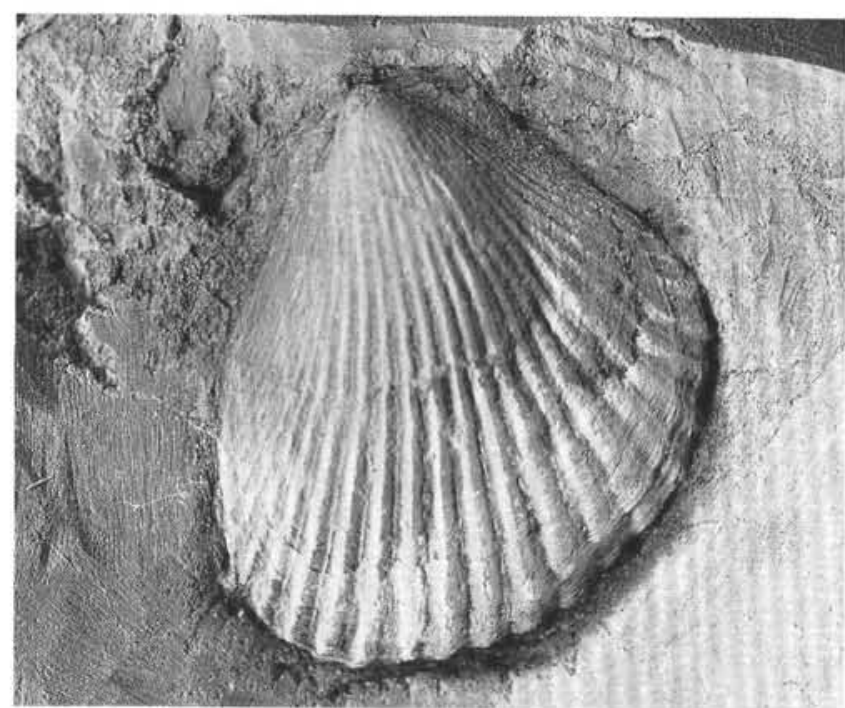

1

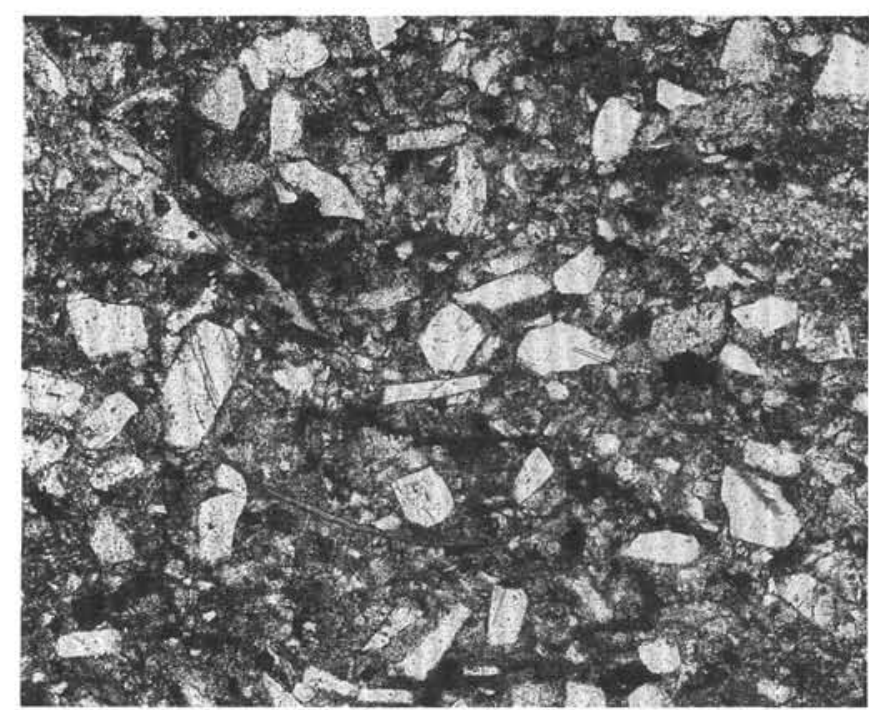

2

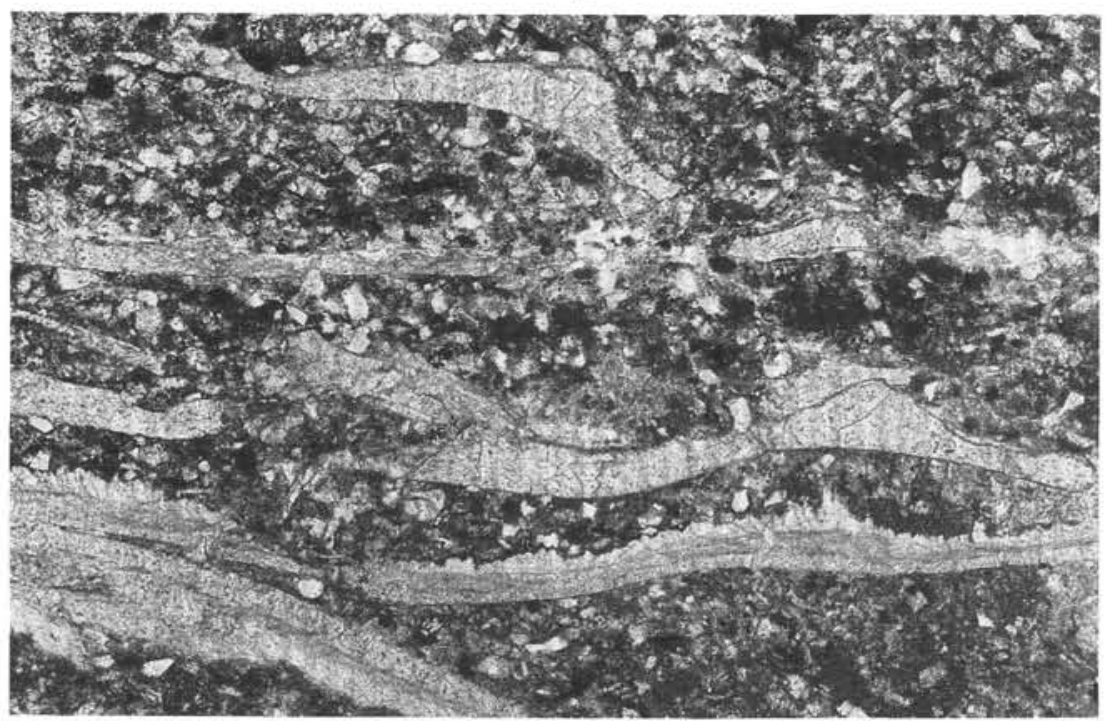

3

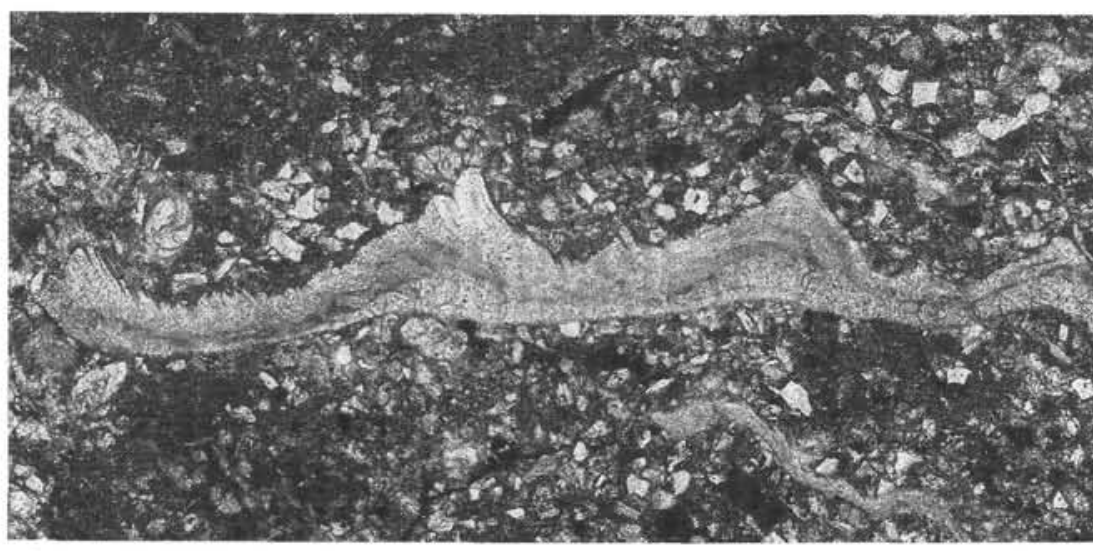

4

Plate 2. 1. Left valve of a Limidae (Pseudolimea sp.?) from Sample 112-688E-40R, CC $(0-4 \mathrm{~cm})$, early Eocene, $4 \mathrm{X}$. 2. Thin section of a sandy mudstone containing angular quartz grains and finely striped plagioclases (left in the picture), Sample 112-688E-40R, CC, early Eocene, 50X. 3 . Thin section of a silty bioclastic mudstone containing ribbed shells, Sample 112-688E-40R, CC (3-5 cm), early Eocene, 38X. 4. Thin section of a ribbed shell showing finely foliated calcitic structure, Sample 112-688E-40R, CC $(0-4 \mathrm{~cm})$, early Eocene, 38X. 